\title{
Residential Toponyms and Urban Change (1890-2000) in a Seaside Resort Town, Benicàssim, Spain
}

\author{
Vicent Ortells Chabrera \\ Universitat Jaume I, Castellón de la Plana, Spain \\ ROBERT B. KENT \\ California State University, Northridge, CA, USA
}

This paper examines the naming patterns of residential dwellings in a seaside resort town, Benicàssim (Valencia), on Spain's Mediterranean coast. The fieldwork encompassed a survey of over 500 dwelling units along the town's coastal margin which has been developed over the last 100 years. Names, specifically personal names and surnames, are most commonly used, with women's name's being most frequent. Almost invariably these are associated with single-family dwellings. Geographical referents, usually of invoking exotic destinations and references to the sun and sea represent other significant categories. These names are used as toponyms for apartment buildings and other multi-unit residences. Recent naming patterns, usually for apartments, include a number of made-up names using prefixes or suffixes referring to the local area.

KEYWORDS Names, residential dwellings, urban development, toponyms, tourism, Spain

\section{Introduction}

Although its etymology derives from Greek, the term toponym, as a reference to a geographical placename, did not come into common usage in English until the end of the nineteenth century. The literature on place names is vast. Scholars and aficionados have plumbed the richness and mystery of place names for well over roo years and the range of perspectives and scales of this body of research are truly staggering. Studies focus on place names in specific languages, some with worldwide usage like English (Ekwall, I960; Mills, I998), and others whose usage is limited to comparatively small geographical areas and peoples whose numbers are few or are no longer even extant (Vogel, I983; Wichman, I998). Others, for example, examine 
place names in a whole host of geographic scales - worldwide (Mathews, I972), continents (Stewart, I970), nations (Johnston, I903), states or provinces (Bright, 2004; Gudde, 2004), counties (Cameron, I985), cities (Empson and Vadnais, 2006), and neighborhoods and streets (McNamara, I99I).

Given the immense range of scales and vast number of placenames, past and present, it is not surprising that the literature on placenames at the local and neighborhood level is comparatively sparse. Nevertheless, some scholars recently have begun to focus on the use of toponyms at the most local or intimate of scales, deemed by some as micro-toponymic studies. Recent examples from the literature include studies examining naming patterns of cemeteries and memorial parks (Tarpley, 2006; Zelinsky, I990), churches (Room, I992; Stump, I988; Zelinsky, 2002), beauty salons (Wilhelm, I988), schools (Hipólito Sesé, 2002) ski trails (Millward and Millward, I984), and apartment buildings (Koegler, I986; Norton and Patterson, I984). If past is prologue, as is often suggested, it is likely more studies in the future will examine the names of places and geographic features at the most local of scales. This indeed is the objective of the present paper.

Toponyms can refer to places of all geographical scales and dimensions and can change over time for a wide variety of reasons. Placenames with the most staying power usually correspond to significant geographical or human features of the landscape, e.g. mountain ranges, rivers, valleys, peaks, towns, and country names. However, placenames do change and these can reflect dramatic human events like migrations, invasions, conquests, or other more mundane occurrences which reflect changing political climates, social values, or simply population change. During the early twentieth century for example, many neighborhoods in North American cities were settled by Italians and "Little Italy" was widely used to describe these places. By the end of the twentieth century, the Italians were gone and their descendants have moved to the suburbs. While the neighborhood name, "Little Italy," is still used to describe the neighborhood as it does in Cleveland, Ohio, for example, little evidence of the previous inhabitants remains, save a few tourist restaurants. Street names and other place names for features of the urban landscape are frequently changed to reflect political events and social issues. In the United States, the proliferation of streets, avenues, and other urban features named for John F. Kennedy and Martin Luther King Jr. after their assassinations in the late I960s are notable examples.

In Spain, place names used in cities and towns for streets, plazas, and other landmarks have changed frequently over the course of the twentieth century. These changes have reflected the events of the Spanish Civil War, the long period of Franco's fascist dictatorship, and the dramatic modernization of the country in the last quarter of the twentieth century after Franco's death. At a more micro-level, in many Spanish cities and towns, and especially in more upscale neighborhoods, residents will sometimes give their homes names. In Spain, however, this practice is much more common in towns which serve as vacation and tourist centers and where homes may have a 'special' meaning to their owners and the use of toponyms on residential dwellings is relatively frequent.

The objectives of this paper are twofold. First, it seeks to document the occurrence of this phenomenon in one Spanish resort town, thought to be characteristic, at least in some ways, of the custom of naming residential dwellings. As such it describes the current practice as it is manifested in one town's urban landscape and includes a 
detailed inventory of extant names and naming patterns in that place. The research also explores subsidiary issues including the size, placement, and materials used to place these names on residential dwellings. Secondly, the paper explores the relationship between the major socio-economic and political periods of Spanish history since the late nineteenth century and the patterns of residential place name evolution and urban change.

\section{Geographical and historical context}

Benicàssim, one of many seaside resorts along the Spanish coast has been selected as the case study site for this research. Benicassim is a municipality, somewhat akin to a county in the USA, situated in the province of Castellón in the region of Valencia. It lies adjacent to the Mediterranean Sea (Piñón and Armiño, I982; Quereda, I979). The town's name is spelled in this manuscript using the local Valencian variant rather than the Castilian version, Benicasim. Over half of the municipality's area is urban, and much of that is devoted to residential housing of various kinds. During the last soo years, the municipality's urban area has grown from a small agricultural village with a population of a few hundred, to a weekend and seasonal tourist destination, with a population in the summer months reaching nearly 150,000 . The municipality's urban growth has paralleled the social, political, and economic events that have transformed Spanish society over the past century and these changes are reflected in the town's urban geography and cultural landscape. More particularly its development also has been similar in many respects to the evolution of tourist landscapes in Spain during the last half of the twentieth century (Pacione, 1977; Parsons, I973).

During most of the nineteenth century, Benicàssim was a small agricultural village situated about one kilometer from the Mediterranean Sea along the main road that connected Valencia with Barcelona. A modest agricultural economy provided a range of products to Castellón and other urban areas, but it also specialized in the production of muscatel grapes (Ginés Escuder, I972). Since the I970s however, the town's urbanized area has expanded tremendously and now covers an area that runs nearly seven kilometers along the Mediterranean Sea and about one kilometer inland. The town's historic core, called the pueblo or just the "town" locally, is still the focus of commercial activity. (In this manuscript all foreign words are placed in italics except those that are proper or placenames. Thus, names given to houses, bungalows, apartments, and other dwellings, whether in Spanish or any other language, are not italicized.) Banks, grocery stores, restaurants, hotels, and all manner of business activity concentrate along an approximately one kilometer stretch of street (Calle Santo Tomás) that was once the route of the old highway between Valencia and Barcelona. Today a national highway and a modern toll road bypass the town's urban core and serve to connect these major urban areas. There is virtually no extant commercial agricultural activity in the town or its environs today and its principal economic activity is directly related to tourism and driven by the beach and the sun.

The first tourist development occurred in the I870s, coincident with the construction of the railroad line along the coast (Aguilar Civera, 2006; Ortells Chabrera, 2006). This construction took place in an idyllic spot at the northeastern edge of the town's political limits and at the end of the beach along a somewhat protected embayment. Indeed, it was the civil engineer who was in charge of the construction 
of the Benicàssim leg of the route, Joaquín Coloma Grau, and his wife, Pilar Fortis Mas, who recognized the attractive qualities of the town's uninhabited beach front and built the first villas between I879 and I893; Villa Pilar, Villa Coloma, and Villa Teresa. Another well-known villa, now gone, was El Palasiet (the Little Palace), built in 1887 . Soon this area, separated from the original agricultural village by approximately two kilometers, came to be known as the "Villas of Benicàssim," a name still used to identify this part of town. The railroad, once completed, eased the difficulties of reaching the town from both Barcelona and Valencia and served to open up the area to further tourist development. This early development was clearly upscale and reserved for only the wealthy who could afford to build summer homes (villas) there and spend all or substantial parts of each summer at the beach (Sarthou, I9ro).

It is useful to note that mass tourism has never been part of the town's tourist economy (Nácher Escriche, I996). Villas and small independent dwellings predominated along the beach until the I970s. By that time improvements in transportation and Spain's economy generally allowed a wider range of social and economic classes to vacation regularly at the beach or in other resort areas. Apartment buildings, usually not exceeding ten stories, and other multi-unit residential developments became commonplace. These other multi-unit developments are known as bungalows and adosados in Spain, and are similar to condominiums or low-density apartments in the United States. During the last decades of the twentieth century, Benicàssim's political establishment moved to eliminate low-end tourist options in the town, especially camp grounds, and have them replaced with more substantial residential dwellings. Hotel-based tourism is not common and never has been. Only one hotel, the Hotel Voramar, sits on the beach in the Villas and only one or two others are even located within a block or so of the beach. There are only about ten permanent hotels in the entire urban area, with an additional number of seasonal inns and hostels opening in the summer months. No new hotel has opened in the town in almost thirty years. At the present, most of the town's tourists are from the local area (Castellon and Valencia) and family vacationing is the norm. Foreigners comprise a comparatively small proportion of the town's seasonal tourists or permanent residents.

\section{Methods and sources}

Geographical fieldwork has been the principal source of data for this study. The field work focused on residential dwellings in the town's "tourist or seasonal residential zone," an area running along the coast about seven kilometers and inland about 500 meters and roughly coincident with the old railroad line that ran along the coast. An inventory of all residential buildings (villas, condominiums, apartments, camp grounds, and residential hotels) included recording addresses, residential dwelling type, the presence or absence of names, the names, and the physical characteristics of the signage used to portray the names - sizes, materials, and their placement on dwelling unit or its grounds. A small number of hotels and camp grounds are included here, approximately Io in total, because these are often occupied by longterm residents during the summer months and serve in many ways more as residential properties than short-term stay hotels or camps. Subsequently, in an effort to understand the patterns revealed in the data, the building names have been categorized by types of names and as well by the age of each building's construction. In all, nearly 
500 residential properties are included in the survey. The vast majority of all buildings are named. Indeed, in the case of apartment buildings and condominium complexes, all are named, but only about 80 percent of single-family residences (villas).

\section{Results}

The naming of residential dwellings is a personal decision taken by the building's owner or family, but it also involves a public statement as well. This of necessity takes the form of some kind of public manifestation of the dwelling's name placed in a visible and prominent spot where it can be seen by the passers-by and the public at large. The first villas constructed along the town's beachfront during the late nineteenth century and early decades of the twentieth century had their names placed in prominent locations on the front of the building facing the beach, usually in an elevated position, and often in plaster and distinguished from the remainder of the building by use of a different color of paint. In some instances, the name was also repeated in wrought-iron work over an entry gate. Thus, the use of large lettering, a visible location, and sometimes repeating the name in more than one place on the property served to distinguish these early villas one from another (Figure I).

As the town grew and the predominant type of construction changed from the early single-family villas to multi-unit residential dwelling like condominiums and apartments, so did the materials used to adorn these buildings with their respective

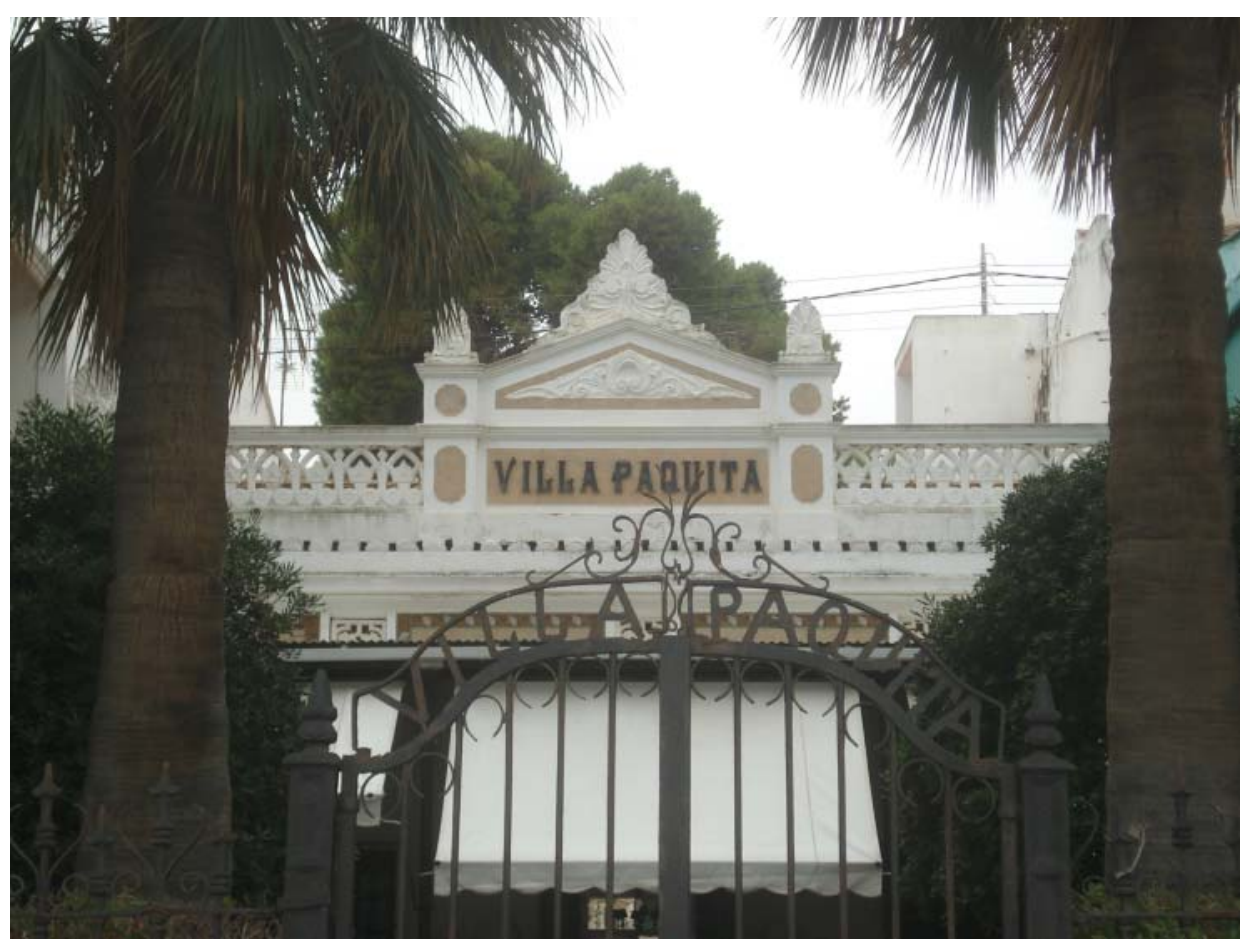

FIGURE 1 Villa Paquita, located along the beachfront promenade, is named in plaster across the front of its façade and on the wrought iron gate to the property. 
names. For instance, the early apartment blocks of the I970s and later also used large lettering, but usually changed the medium to paint. These names would often be painted on the building's exterior walls or the fences surrounding them and sometimes would be supplemented by metal or neon signs placed at the complex's entrance. In the last few decades, the use of ceramic tile signs has become more frequent in the area, following no doubt the rise of the province to which Benicassim belongs (Castellón de la Plana) to the principal producer of ceramic tile in the entire country (Ortells Chabrera, 2005). These ceramic signs are often elaborate affairs including not just a name, but also some sort of artistic flourishes. For example, one apartment complex, called Los Naranjos (the Oranges) boasts a lovely ceramic sign including not just its name but orange branches heavy with fruit (Figure 2). In some cases, however, distinctive signage is absent, and in place of it buildings are identified by small utilitarian signs exactly like those used for highway signs in Spain. This situation occurs almost exclusively with large apartment buildings.

Language usage in building naming follows an expected pattern. Spanish dominates as the principal language. Slightly over 70 percent of all names which could readily be identified as being linked to a specific language $(n=403)$ are in Spanish. Catalan, also known here as Valencian, is widely spoken by the local population and is also used to name buildings frequently as well. Some $\mathrm{I} 8$ percent of all names identified in this study are Catalan in origin. A smattering of other languages is also used. Names in classical languages (Latin and Greek), English, Italian, Basque, Arabic, and others total just slightly more than Io percent.

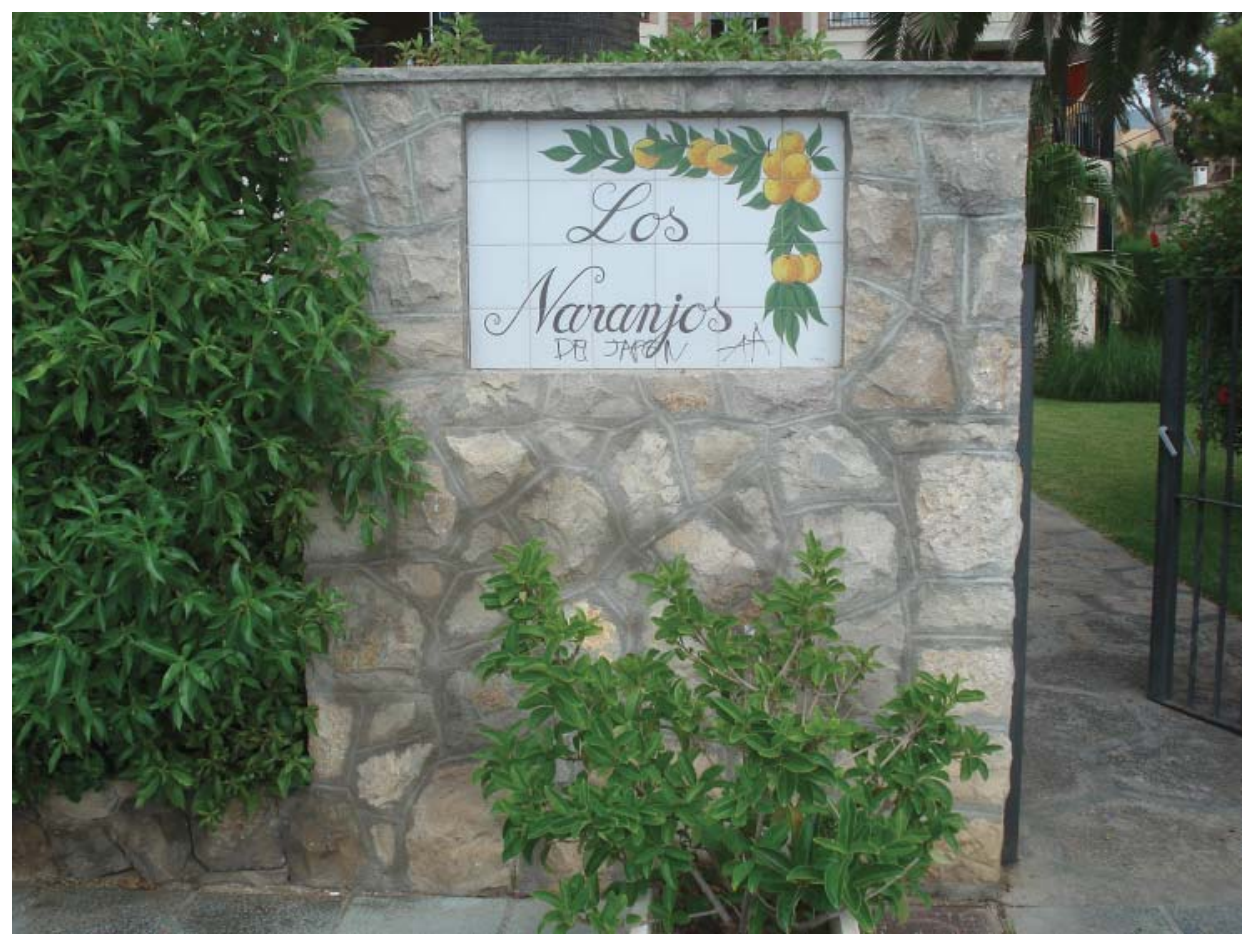

FIGURE 2 Decorative ceramic tile are used to create the naming sign for the beachfront apartment complex, Los Naranjos. 
Despite its status as a tourist center, Benicàssim is distinct from some other tourist towns in Spain and other countries where foreign languages have come to figure dominantly in the cultural landscape. English, for instance, has reached such a status in Benidorm, another beach town in southern Valencia, where British tourists and residents exert a strong influence on the urban landscape. Similar patterns occur in other tourist towns dominated by foreigners, as has been the case in Los Cabos, in Baja California (México) where visitors from the United States have had a profound impact on language use on the cultural landscape (Hoffmann, I992). It is also important to note that, while Benicàssim does fall in an area of mixed language use where both Valencian ("southern" Catalan) and Spanish (Castilian) are spoken, there does not seem to be any significant linguistic nationalism revealed in the patterns of residential dwelling naming that occurs here.

The names used to identify these residential dwellings are often ephemeral. A change of ownership or historic events can create change. The Spanish Civil War (I936-I939) provides one such example. During much of the war, the Hotel Voramar and nearly forty other villas along the beach were occupied by convalescing soldiers from the International Brigades who fought with the pro-democracy forces of the Republican's against Franco's fascist Nationalist alliance. The names of a number of villas were changed to honor heroes of the Republican and Internationalist causes, such as Álvarez del Vayo and General Miaja. With the eventual victory of Franco's fascist forces and the imposition of a dictatorship, these names quickly disappeared from villa façades.

The history of the names of one particular villa, and the families which have occupied it, also illustrates this phenomenon well and such is the case of a beachfront property constructed in 1893 (Burriel Orueta, 2008). This particular villa, situated less than 50 meters southwest of the Hotel Voramar, sits on the beachfront promenade. This is a highly desirable location and has been since the Villas of Benicàssim were originally settled. The villa was constructed for Vicente Carles, a well-to-do Valencian. Carles named the villa for his wife, and it was known as Villa Candida. When Carles died in I9I0, the property was inherited by two daughters and later subdivided by them into two dwellings, one upstairs and one downstairs, for their use and eventually that of their extended families. They renamed the villa for their paternal side, and it became Villa Carles. During the Spanish Civil War, the villa was requisitioned for nearly three years by the Republican forces for use as a convalescent hospital. It was renamed in honor of one of the Republican cause's luminaries and heros, Álvarez del Vayo. Returned to its owners after the war, the villa again became Villa Carles. In 1975 the surviving sister, Elvira Carles, died, and the villa was sold to Eugenio Méndez Vigo, who promptly renamed the villa for his family, MéndezVigo. Although he has since died as well, his daughter and son-in-law who now own the property have maintained the name.

The assignation of names to residential dwellings is usually a personal matter decided by the building's owner, family, or a developer. Sometimes the public assigns nicknames to particularly distinctive dwellings and these take on a life of their own. One such example is a villa constructed along the beachfront in the late nineteenth century and distinguished by large tower. Despite its distinctive character, prominent location on the beachfront, and its size, the owners of this dwelling have not assigned it a proper name in contrast to almost all the neighboring buildings. It is used as a 
geographical referent by many, and simply known popularly as La Torreta (the Little Tower). One particularly ribald, or perhaps offensive example of public naming, depending on one's point of view, is the House of the Buttocks (Villa del Culs), an allusion to body parts of the naked statues that sit on its front terrace. This beachfront villa, actually called Solimar (sun and sea), was constructed by a sculptor and professor of art, Sanchis Yago. It boasts three nearly life-sized naked masculine statues of Atlantis placed on its second-story porch facing the beach and seaside promenade. But out of modesty these were placed with their buttocks (culs in Valenciano) facing the public. Other local nicknames for residential dwellings refer to the owner's occupation, such as the Villa del Comisario (the Policeman's Villa) and the Villa del Boticario (Pharmacist) Ribes.

\section{Contemporary residential naming patterns}

Names, broadly defined to include first names, surnames, Catholic saints, and historic personages, dominate the pattern of residential naming found in Benicàssim and account for almost 40 percent of the total (Table I). This personalization of residential space is dominated by women's names, primarily Spanish in origin, which represent over one-fifth of all recorded names $(22$ percent). Typically, these are traditional Spanish first names with some appearing multiple times, e.g. Pilar, Carmen, Ana, Cristina, and Margarita. Nevertheless, women's nicknames and diminutives are also used with some frequency. Female names in other languages are uncommon and only a handful from Catalan, Basque, and English were identified in this study. Typically, women's names are used almost exclusively on villas (large, imposing residences of the wealthy) and other single-family dwelling units. In only one case was a woman's name associated with an apartment building or other multi-unit residential dwelling. A handful of dwellings, again usually villas, are denominated with compound names. These appear to represent the names or nicknames of married couples who are, or were, the dwelling's owners (e.g. Manolo y Loli, Toki-Eder). Men's names are used in a few cases (I.8 percent), but these are usually associated with apartment buildings.

Surnames also figure prominently among the toponyms used for dwellings in Benicassim. As is the case with women's names, surnames are most typically associated with single-family residences, villas and the like, constructed during the beginning of the twentieth century when the town became a favored summer resort destination for the social elite of Valencia and nearby Castellón. All told, just over 8 percent of the dwellings surveyed here are identified by surnames (Table I). Valencian (e.g. Oliag, Comin, Roig, Carpi) and Spanish (García, Hurtado, Romero) surnames predominate, as well as a sprinkling of surnames of diverse origins (Arab, German, Polish, and Italian).

A spattering of other names is also used (4 percent). Generally these fall into two categories - titles, historic personages, and saints and religious invocations. Particularly striking among these are El Paraíso (Paradise), El Cel (heaven in Catalan), and, perhaps most astonishing, Villa de Dios (God's Villa).

Place names, more often than not, invoking images of the exotic or far away tourist destinations represent approximately 20 percent of the residential toponyms identified in Benicassim (Table I). The use of these place names is primarily associated with apartment blocks and condominium complexes. Most of these were constructed 
TABLE 1

TOPONYMS USED FOR RESIDENTAL DWELLINGS IN BENICÀSSIM, SPAIN

\begin{tabular}{|c|c|c|c|c|}
\hline \multicolumn{3}{|l|}{$\begin{array}{l}\text { Category } \\
\text { Names }\end{array}$} & Number of Names & Percent \\
\hline \multicolumn{5}{|c|}{ Women's Name - Spanish } \\
\hline Adela & Encarna (2) & Marina & & \\
\hline Alicia & Esperanza & Mercedes & & \\
\hline Amelia & Esther & Milagros & & \\
\hline Amor & Eva & Monserrat & & \\
\hline Amparo & Gertrudis & Olga & & \\
\hline Ana (2) & Gloria & Patricia & & \\
\hline Araceli & Gracia & Piedad & & \\
\hline Beatriz & Helena & Pilar (3) & & \\
\hline Bienvenida & lluminada & Rosa Magda & & \\
\hline Carlota & Isabel & Rosalía & & \\
\hline Carmen (3) & Lolin & Sagrario & & \\
\hline Carmen Adela & Manuela & Sandra & & \\
\hline Celia & Margarita (2) & Sara & & \\
\hline Clotilde & María & Sonia & & \\
\hline Cristina (2) & María del Carmen & Teresa & & \\
\hline Delfina & María Julia & Verónica & & \\
\hline Elisa & María Luisa (2) & Victoria & & \\
\hline Elvira & María Rosa & Virginia & & \\
\hline \multirow[t]{2}{*}{ Emilia (2) } & María Teresa & & & \\
\hline & & & 74 & 15.1 \\
\hline \multicolumn{5}{|c|}{ Women's Name - Catalan } \\
\hline \multirow[t]{2}{*}{ Joana } & Lledoneta & Quimeta & & \\
\hline & & & 3 & 0.6 \\
\hline \multicolumn{5}{|c|}{ Women's Name - English } \\
\hline \multirow[t]{2}{*}{ lany } & Rosemary & Sylvia & & \\
\hline & & & 3 & 0.6 \\
\hline \multicolumn{5}{|c|}{ Women's Name - Compound } \\
\hline Amaralina & Gemaida & Marilis & & \\
\hline Bealbe & Maimen & Mariló & & \\
\hline \multirow[t]{2}{*}{ Dienina } & Marelén & Marisa & & \\
\hline & & & 9 & 1.9 \\
\hline \multicolumn{5}{|c|}{ Women's Name - Shorhand } \\
\hline Almu (Almudena) & Francis (Francisca) & $\begin{array}{l}\text { Maguies } \\
\text { (Magdalena) }\end{array}$ & & \\
\hline Chedes (Consuelo?) & Isa (Isabel) & Norber (Norberta) & & \\
\hline Chus (María lesús) & Lala (Dolores?) & Susan & & \\
\hline Cuca (Concepción) & Magdala (Magdalena) & Tonia (Antonia) & & \\
\hline \multirow[t]{2}{*}{ Evir (Elvira) } & Magne (Magdalena) & Trini & & \\
\hline & & & 15 & 3.1 \\
\hline
\end{tabular}


TABLE 1

CONTINUED

\section{Category \\ Names}

Number of Names

Percent

Women's Name - Diminutives

$\begin{array}{lll}\text { Adelina } & \text { Josefina } & \text { Socorrito } \\ \text { Angelines } & \text { Paquita } & \text { Vicentica }\end{array}$

Antoñita

Women's Name - Basque

Estívariz

Men's Name

Deifontes

Josacho (José)

Vicente

Don Pepe (José)

Josama (José María)

Ygor

Gaspar

Manuel

Hermenegildo

Mateu

Men and Women's Name

$\begin{array}{lll}\text { Arlette y Vicente } & \text { Erijer } & \text { May-Vir } \\ \text { Eben-Ezer } & \text { loyja } & \text { Tavi-Roc } \\ \text { Ediben } & \text { Manolo y Loli } & \text { Toki-Eder } \\ \text { Feysal } & & \end{array}$

Spanish Surnames

$\begin{array}{lll}\text { Alagarda } & \text { Hurtado } & \text { Sánchez } \\ \text { Callao } & \text { Larza } & \text { Sanjuán } \\ \text { Galván } & \text { Luján } & \text { Santos } \\ \text { Gabino } & \text { Méndez-Vigo } & \text { Zúñiga } \\ \text { García } & \text { Romero } & \end{array}$

Valencian Surnames

$\begin{array}{lll}\text { Agost } & \text { Carpi } & \text { Orenga } \\ \text { Alegre } & \text { Casañ (2) } & \text { Pons } \\ \text { Barrachina } & \text { Comín } & \text { Rambla } \\ \text { Bernat } & \text { Cotolino } & \text { Rius } \\ \text { Cardona } & \text { Oliag } & \text { Roig }\end{array}$

Other Surnames

$\begin{array}{lll}\text { Allschwill } & \text { Furaliss } & \text { Rumah-Saya } \\ \text { Camilleri } & \text { Hornia } & \text { Tachiños } \\ \text { Chassan-Boulos } & \text { larrub } & \\ & \text { Rokiski } & \end{array}$

Historic Persons and Titles

$\begin{array}{lll}\text { Ambassador } & \text { Emperador } & \text { Ribalta } \\ \text { El Cid } & \text { Los Príncipes } & \\ \text { El Palleter } & \text { Princicasim } & \end{array}$


TABLE 1

CONTINUED

\begin{tabular}{|c|c|c|}
\hline \multicolumn{3}{|l|}{$\begin{array}{l}\text { Category } \\
\text { Names }\end{array}$} \\
\hline \multicolumn{3}{|c|}{ Catholic Saints and Religious Images } \\
\hline El Cel & Santa Águeda & Santa R \\
\hline El Paraíso & Santa Cristina & Villa de \\
\hline San laime & Santa Eulalia & Virgen $c$ \\
\hline San José & Santa Marta & \\
\hline \multicolumn{3}{|l|}{ Other Names } \\
\hline Asdi & Kikorola & Pololo's \\
\hline Crisco & Mayoki & Takiline \\
\hline J.P. & Merbea & \\
\hline & Mona Lisa & \\
\hline
\end{tabular}

Number of Names Percent

Santa Rosa

la de Dios

irgen del Pilar

plolo's

kiline

\section{Places}

America

Acapulco

Argentina

Astoria

Atlanta

Borinquén

Brasilia

Costa Brasil

Costa Rica

Del Tempe

\section{Europe}

Alborán

Cabo Sunión

Capri

Coimbra

Delfos

Estoril

Europa

Madeira
Florida

Jamaica

Las Vegas

Los Ángeles

Miami

Miami Beach

Montreal

Nueva Orleans

Mediterráneo Playa

Mediterráneo Vela

Mónaco

Olimpo

Oporto

Palermo

Portobello

Portofino
Palm Beach

Tarapoto

Taxco

Toronto

Tukumán

Veracruz

Viña del Mar

Riviera

San Marino

San Remo

Skorpios

Venecia

Via Apia

Viena

Oceania. Africa and Asia

$\begin{array}{lll}\text { Bali } & \text { Onuba } & \text { Sidney } \\ \text { Costa de Marfil } & \text { Samoa } & \text { Tahití } \\ \text { Hawai } & \text { Sapporo } & \text { Tanzania }\end{array}$


TABLE 1

CONTINUED

\begin{tabular}{lll}
$\begin{array}{l}\text { Category } \\
\text { Names }\end{array}$ & \\
\hline Spain & & \\
Ademuz & Eivissa & Marbella \\
Al-Andalus & Formentor & Monte Gala \\
Albayda & Gran Sol & Nueva Ibiza \\
Canarias & Ibiza & Ordesa \\
Ciudad Ibicenca & Iruña & Porto Cristo \\
Ciudadela & Laredo &
\end{tabular}

Benicàssin and Local Region

$\begin{array}{lll}\text { Beni-Baró } & \text { Carallot } & \text { La Plana } \\ \text { Benicasim } & \text { Columbretes } & \text { Montornés (2) } \\ \text { Benipal } & \text { Els Terrers } & \text { Torrecasim } \\ \text { Centrocasim } & \text { Eurokasim } & \text { Villa Real } \\ \text { Raco d'Or } & \text { Fadrell } & \text { Vilacasim } \\ \text { Benilandia } & \text { Gran Avenida } & \\ & \text { L'llla } & \end{array}$

\section{Sea and Sun}

\section{The Sea}

$\begin{array}{lll}\text { Aigua-Blava } & \text { Horizonte } & \text { Rosmar } \\ \text { Amura } & \text { Las Islas } & \text { Serramar } \\ \text { Azulmar } & \text { Las Rocas } & \text { Sus Mar } \\ \text { Bajamar } & \text { Mar Blava } & \text { Telmar } \\ \text { Bellavista } & \text { Mar Libre } & \text { Terramar } \\ \text { Belumar } & \text { Marazahar } & \text { Trinimar } \\ \text { Benimar } & \text { Marenostrum (2) } & \text { Tumar } \\ \text { Blau-Mar } & \text { Mar-fí } & \text { Urbamar } \\ \text { Broncemar } & \text { Mira Playa } & \text { Urbesol } \\ \text { Carymar } & \text { Miramar } & \text { Villa del Mar } \\ \text { Castellmar } & \text { Montemar (2) } & \text { Villalmar } \\ \text { Claramar } & \text { Pelillos a la Mar } & \text { Villamar } \\ \text { Cortemar } & \text { Peñamar } & \text { Vista Alegre (H) } \\ \text { Costa de Azahar } & \text { Playamar } & \text { Vistamar (2) } \\ \text { Cristal-Mar } & \text { Playasol-1 } & \text { Voramar (H) } \\ \text { Cumbremar } & \text { Playasol-2 } & \text { Yolimar } \\ \text { Curricán } & \text { Plenamar } & \\ \text { Dosbemar } & \text { Randumar } & \\ & \text { Rocamar } & \end{array}$

The Sun

\begin{tabular}{lll} 
Alba & Cortesol & Solimar \\
Amanecer & Eurosol & Urbesol \\
\hline
\end{tabular}


TABLE 1

CONTINUED

\begin{tabular}{|c|c|c|c|c|}
\hline $\begin{array}{l}\text { Category } \\
\text { Names }\end{array}$ & & & Number of Names & Percent \\
\hline Beniluz & L’Estiu & & & \\
\hline \multirow[t]{2}{*}{ Benisol } & Panasol & & & \\
\hline & & & 10 & 2.0 \\
\hline \multicolumn{5}{|l|}{ The Wind } \\
\hline Aireola & Buenabrisa & Ventolera & & \\
\hline Barlovento & Gregal & Xaloc & & \\
\hline \multirow[t]{2}{*}{ Bonaire } & Tramontana & & & \\
\hline & & & 8 & 1.6 \\
\hline \multicolumn{5}{|l|}{ Boats } \\
\hline 3 Carabelas & Kon-Tiki & Los Balandros & & \\
\hline Bergantín & La Falúa & Poseidón & & \\
\hline \multirow[t]{2}{*}{ Calipso } & La Nau & & & \\
\hline & & & 8 & 1.6 \\
\hline \multicolumn{5}{|c|}{ Rest. Enjoyment. and Feelings } \\
\hline Bon Repós (2) & Embrujada & La Siesta & & \\
\hline Bonterra & La Conseguí & Tropicana & & \\
\hline \multicolumn{5}{|l|}{ El Perdido } \\
\hline & & & 9 & 1.9 \\
\hline & & & 94 & 19.1 \\
\hline \multicolumn{5}{|l|}{ Nature } \\
\hline \multicolumn{5}{|c|}{ Vegetations and Crops } \\
\hline 3 Pinos & Las Palmeras & Los Sauces & & \\
\hline Benazahar & Les Parres & Orange $(H)$ & & \\
\hline Botánico & Los Almendros & Pinarlandia & & \\
\hline El Blatet & Los Chopos & Romerets & & \\
\hline El Tamaral & Los Eucaliptus & Tamarindos & & \\
\hline Els Ginjols & Los Juncos & Yucas & & \\
\hline L’Olivera & Los Naranjos & & & \\
\hline La Grandalla & Los Olivos & & & \\
\hline \multirow[t]{2}{*}{ La Pinada } & Los Pinos & & & \\
\hline & & & 24 & 4.9 \\
\hline \multicolumn{5}{|c|}{ Animals and Wildlife } \\
\hline Azor & Guau-guau & La Oroneta & & \\
\hline Coral & Koala & Los Delfines & & \\
\hline \multirow[t]{2}{*}{ Delfín } & La Gaviota & & & \\
\hline & & & 8 & 1.6 \\
\hline \multicolumn{5}{|c|}{ Geographic Features and Spaces } \\
\hline Arenal & La Cascada & Oasis & & \\
\hline Boreal & La Punta & Remolins & & \\
\hline Cumbresol & Las Salinas & Taal & & \\
\hline \multirow[t]{3}{*}{ Delta } & Montañesa & & & \\
\hline & & & 11 & 2.2 \\
\hline & & & 43 & 8.7 \\
\hline
\end{tabular}


TABLE 1

CONTINUED

\begin{tabular}{|c|c|c|}
\hline $\begin{array}{l}\text { Category } \\
\text { Names }\end{array}$ & & \\
\hline \multicolumn{3}{|c|}{ Mythology and Literature } \\
\hline \multicolumn{3}{|c|}{ Gods and The Zodiac } \\
\hline Acuario & Helios & Tauro \\
\hline Aries & Olimpia & Tebas \\
\hline Capricornio & Olimpo & Zeus \\
\hline Géminis & $\mathrm{Ra}$ & \\
\hline Heliópolis & Tanit & \\
\hline
\end{tabular}

Literature and Literary Figures

$\begin{array}{lll}\text { Albórbola } & \text { Dulcinea } & \text { Sotileza } \\ \text { Arlequín } & \text { Embrujada } & \text { Tombatossals } \\ \text { Don Quijote } & \text { El Paraiso } & \\ & \text { Garxolí } & \\ & \text { Ítaca } & \end{array}$

$10 \quad 2.0$

$23 \quad 4.6$

\section{Architecture}

Buildings and Gardens

$\begin{array}{lll}\text { Carrerassa } & \text { El Pouet } & \text { Los Arcos } \\ \text { El Aljibe } & \text { El Ranchito } & \text { Mas Braulio } \\ \text { El Balcó } & \text { Hábitat-80 } & \text { Mas Castell } \\ \text { El Casetó } & \text { La Alcazaba } & \text { Mas Vell } \\ \text { El Chalé } & \text { La Barraca } & \text { Medina Azahara } \\ \text { El Cortijo } & \text { La Noria } & \text { Torremar } \\ \text { El Faro } & \text { La Torre } & \text { Villa Magna } \\ \text { El Pabellón } & \text { La Trilladora } & \text { Villa de Dios } \\ \text { El Poble } & \text { La Villeta } & \\ & \text { Las Terrazas } & \end{array}$

$27 \quad 5.5$

\section{Miscellaneous}

$\begin{array}{lll}\text { Acata } & \text { Gongar } & \text { Orouna } \\ \text { Aldraba } & \text { Gure Am } & \text { Syca } \\ \text { Argenta } & \text { Hellebo } & \text { Toroel } \\ \text { Bersoca }(\mathrm{H}) & & \\ \text { El Perdido } & & \end{array}$

$\begin{array}{rr}11 & 2.2 \\ \mathbf{1 1} & \mathbf{2 . 2} \\ \mathbf{4 9 1} & \mathbf{9 9 . 7}\end{array}$

Total

491

SOURCE: Authors' Field Surveys. 
in the I970s and thereafter as tourism in the town evolved from primarily an activity of the region's social and economic elite to a more generalized pattern of mass tourism accessible to the middle and working classes of the neighboring urban centers of Castellón and more distant Valencia. Geographically, the names of locations in the Americas and Europe occur with the most frequency (over Io percent) and famous tourist destinations are commonly invoked. These include Las Vegas, Miami, Palm Beach, Acapulco, and Viña del Mar in the Americas, and Riviera, San Marino, Capri, and Mónaco in Europe. Spanish place names are also invoked ( 3.6 percent), and again typically these are those of well-known tourist destinations, many in the Balearic Islands - Ibiza, Formentor, and Eivissa (Ibiza in Catalan). Also comparatively common (over 4 percent) are local geographical referents (e.g. La Plana, Columbretes, Villa Real, and Fadrell) and a range of somewhat nonsensical derivatives of the town's name - Princicasim, Villacasim, Eurokasim, Benipal, and Beni-Baró.

As a Mediterranean seaside resort town, invocations of the sun and the sea in residential naming patterns seem likely, and indeed this is the case in Benicàssim. About 20 percent of all residential dwelling names invoke such images. The sea, sea views, or compound invented words utilizing the sea (mar in Spanish) are most common (I2 percent). Compound names are most frequent in this category. These include names associated with views of the sea and beach, e.g. Miramar, Vistamar, Playamar, and Mira Playa, those that play on images of both the sea and the nearby mountains which rise up nearly 500 meters immediately behind the town, e.g. Serramar, Montemar, Cumbremar, and Roca Mar, or a location near the sea such as Plenamar, Bajamar, Sus Mar, or Torremar (a fifteen-story apartment building located immediately adjacent to the beach). Some names simply invoke the sea using the word mar as suffix, but otherwise are somewhat opaque in their meaning, for example Randumar, Tumar, Dosbemar, Belumar, Trinimar, Carymar, Yolimar, and Telmar. Other sub-categories of names invoke the sun (2.5 percent), the wind (I.7 percent), boats (I.7 percent) and rest, relaxation, and feelings (I.7 percent).

The remaining 20 percent of residential dwelling names fall into four broad categories (Table I). The nature and the environment, including vegetation and crops, animals and wildlife, and geographic features and spaces represent 9 percent of all toponyms, while mythology and literature accounts for over 4 percent as do references to various kinds of buildings and elements of the build environment (e.g. El Faro, Las Terrazas, La Torre, Los Arcos). Finally, about 4 percent could not be definitively categorized. These include Gongar, Mayoki, Erijer, Asdi and others of uncertain etymology.

\section{Urban change and the evolution of residential naming patterns}

As noted earlier in this paper, the names assigned to residential dwellings are not permanent. Properties change ownership, buildings are razed, and the social and political fashions of the day become outdated and customs change. In order to more fully understand the custom of residential naming, it is useful to attempt to examine it not just as it manifests itself on the contemporary landscape, but also in terms of its historic evolution since these patterns likely bear a relationship with the periods and social, economic, and political change. In the case of Benicassim, the naming of 
residential dwellings began during the last decades of the nineteenth century and has continued since then.

\section{Las Villas de Benicàssim: A romantic landscape (1879-1940) - feminine names and surnames}

For a small town, rapid urban growth took place in the first years of the twentieth century. The census of I9Io registered 53 buildings (dwellings) that extended discontinuously along what is called in Spain, la primera linea or the first line, that is, properties on the beachfront, promenade, or beachfront road with direct access to the beach. This area extended from Las Villas down the beach to the Torre de Sant Vicent a distance of about I.5 kilometers. The first villas were generally modest in conception and execution, and often resembled the simple country farms or estates of the La Plana region, masets (López Gómez, I972). Indeed, in the countryside these masets often are given place names as well (Verge Caballer, 2006). One-story buildings with a back porch and a small entry garden typified these villas, as often did two palm trees planted in the front yard. Over its front façade, a name was usually inscribed using plaster; Villa Vicentica, Villa Marina, and Villa Isabel are extant examples of this style. In some cases, others expanded on the simple maset design and added a second story, often with ostentatious airs and designs typical of the bourgeois of the period and places they idealized and sometimes frequented, the Italian Rivera, Piamonte (Villa Pilar), Biarritz, and the France's Costa Azul (Villa Victoria), or Spanish-American Colonial (Villa Amparo). Owners of these villas also constructed their own bathing houses along the water's edge in front of their houses.

Only 3.5 percent $(n=I 7)$ of the residential dwellings with names which are documented in the present study date from this early period (Table 2). These are, however, some of the most elegant and distinguished homes found in the town. Most of the villas were named for women, substituting names for addresses and in the minds of some representing a pleasing replacement for an impersonal street number and street name (e.g. Villa Pilar, Victoria, Socorrito, Rosario, Lola, Sofía, Amparo, Isabel, Carmen, María, Ana, and María Luisa). Names do not seem to repeat themselves, perhaps through some tacit agreement. Nor does the name of a man occur in even one instance. Family names do occur in two cases, Carpi and Pons.

The building of new villas was nearly stopped between I9I0 and I930. Perhaps the most important development along the Villas beachfront was the construction of a restaurant in 1930 at the foot of the beach and the hills to the northeast. This restaurant was converted into the Hotel Voramar in 1933 becoming the only commercial building along the beachfront of Las Villas. It was and continues to be known by most locals to this day as simply Voramar.

A scant three years later, as the Spanish Civil War (I936-I939) ensued, Benicàssim was transformed from a vacation escape of the bourgeoisie of Castellón and Valencia, into a place of hospitals, convalescent homes, and schools. The buildings were not generally transformed in any significant architectural sense, but the romantic ambiance of the place evaporated and the reality of war impressed itself on the beachside town. Many of the names of the confiscated homes were changed from those of their original baptism to new names related to personalities and heroes of the Republican 
TABLE 2

TOPONYMS USED FOR RESIDENTAL DWELLING BY TIME PERIOD IN BENICÀSSIM, SPAIN

Time Period

1870-1940

Names

$\begin{array}{lll}\text { Amparo } & \text { Gracia } & \text { Pons } \\ \text { Ana } & \text { Isabel } & \text { Socorrito } \\ \text { Carmen } & \text { María } & \text { Vicentica } \\ \text { Carpi } & \text { María Julia } & \text { Victoria } \\ \text { Elisa } & \text { María Luisa } & \end{array}$

The Sea and Sun

Villa del Mar

Voramar

Construction

Mas Braulio

lluminada

Isa

Marina

Méndez-Vigo

Gloria

Places

Argentina

The Sea and the Sun

Vistamar

Construction

El Pouet

Torrecasim

\section{1-1980}

Names

$\begin{array}{lll}\text { Adela } & \text { Elvira } & \text { Milagros } \\ \text { Adelina } & \text { Emilia } & \text { Mona Lisa } \\ \text { Alegre } & \text { Encarna } & \text { Montserrat } \\ \text { Alicia } & \text { Erijer } & \text { Olga } \\ \text { Ambassador } & \text { Feysal } & \text { Oliag } \\ \text { Amor } & \text { Francis } & \text { Piedad } \\ \text { Ana } & \text { Furaliss } & \text { Pilar } \\ \text { Barrachina } & \text { Galván } & \text { Los Príncipes } \\ \text { Bealbe } & \text { Géminis } & \text { Princicasim } \\ \text { Bienvenida } & \text { Helena } & \text { Rambla }\end{array}$


TABLE 2

CONTINUED

\begin{tabular}{|c|c|c|c|c|}
\hline Time Period & & & Number of Names & Percent \\
\hline Carmen & Heliópolis & Romero & & \\
\hline Casañ & Hornia & San José & & \\
\hline Casañ & lany & Sánchez & & \\
\hline Chus & Jarrub & Sandra & & \\
\hline Clotilde & Josama & Santa Àgueda & & \\
\hline Comín & Lala & Santa Marta & & \\
\hline Cristina & Larza & Santa Rosa & & \\
\hline Cristina & Lledoneta & Tachiños & & \\
\hline Cuca & Lolín & Takiline & & \\
\hline Deifontes & Maguies & Tanit & & \\
\hline Delfina & Manolo y Loli & Teresa & & \\
\hline Don Pepe & Margarita & Tombatossals & & \\
\hline Don Quijote & María del Carmen & Tonia & & \\
\hline Dulcinea & María Rosa & Virginia & & \\
\hline \multirow[t]{4}{*}{ El Cel } & María Teresa & Ygor & & \\
\hline & Marisa & Zeus & & \\
\hline & Mercedes & Zúñiga & & \\
\hline & & & 79 & 16.1 \\
\hline \multicolumn{5}{|l|}{ Places } \\
\hline Acapulco & Iruña & Samoa & & \\
\hline Bali & Las Vegas & San Remo & & \\
\hline Benicasim & Los Ángeles & Sidney & & \\
\hline Benisol & Madeira & Skorpios & & \\
\hline Canarias & Mediterráneo & Tahití & & \\
\hline Capri & Miami & Torrecasim & & \\
\hline Coimbra & Miami Beach & Tukumán & & \\
\hline Columbretes & Montañesa & Venecia & & \\
\hline Costa Rica & Montornés & Veracruz & & \\
\hline Delfos & Montreal & Vilacasim & & \\
\hline Del Tempe & Olimpia & Viña del Mar & & \\
\hline Estoril & Oporto & & & \\
\hline Europa & Ordesa & & & \\
\hline Eurosol & Palermo & & & \\
\hline Florida & Porto Cristo & & & \\
\hline \multicolumn{5}{|l|}{ Hawai } \\
\hline \multicolumn{5}{|l|}{ lbiza } \\
\hline & & & 43 & 8.7 \\
\hline \multicolumn{5}{|l|}{ Sea and Sun } \\
\hline Acuario & Gregal & Miramar & & \\
\hline Amanecer & Heliópolis & Montemar & & \\
\hline Amura & Helios & Peñamar & & \\
\hline
\end{tabular}


TABLE 2

CONTINUED

\begin{tabular}{|c|c|c|c|c|}
\hline Time Period & & & Number of Names & Percent \\
\hline Azulmar & Horizonte & Plenamar & & \\
\hline Los Balandros & Kon-Tiki & Remolins & & \\
\hline Bellavista & L'llla & Rosmar & & \\
\hline Belumar & La Gaviota & Serramar & & \\
\hline Benimar & La Nau & Solimar & & \\
\hline Bergantín & La Punta & Telmar & & \\
\hline Blau-Mar & Las Islas & Terramar & & \\
\hline Bonaire & Las Rocas & Tramontana & & \\
\hline Calipso & Los Delfines & Ventolera & & \\
\hline Claramar & Mar Blava & Villalmar & & \\
\hline Coral & Mar Libre & Vista Alegre & & \\
\hline Costa de Azahar & Marazahar & Vistamar & & \\
\hline Cumbremar & Marenostrum (2) & & & \\
\hline Cumbresol & Mar-fí & & & \\
\hline \multicolumn{5}{|l|}{ Curricán } \\
\hline \multicolumn{5}{|l|}{ Delfín } \\
\hline \multicolumn{5}{|l|}{ El Cel } \\
\hline & & & 54 & 11.0 \\
\hline \multicolumn{5}{|c|}{ Vegetation and Crops } \\
\hline 3 Pinos & Los Juncos & Oasis & & \\
\hline La Pinada & Los Naranjos & Orange $(\mathrm{H})$ & & \\
\hline Les Parres & Los Olivos & Tamarindos & & \\
\hline \multirow[t]{2}{*}{ Los Eucaliptus } & Los Sauces & Yucas & & \\
\hline & & & 12 & 2.4 \\
\hline \multicolumn{5}{|l|}{ Architecture } \\
\hline El Faro & Habitat-80 & La Trilladora & & \\
\hline El Poble & La Alcazaba & Los Arcos & & \\
\hline \multirow[t]{3}{*}{ El Ranchito } & La Noria & Medina Azahara & & \\
\hline & La Torre & & & \\
\hline & & & 10 & 2.0 \\
\hline \multicolumn{5}{|l|}{ Other } \\
\hline Astoria & Bonterra & La Oroneta & & \\
\hline Azor & Capricornio & La Siesta & & \\
\hline \multirow[t]{4}{*}{ Bon Repós (2) } & Guau-guau & Tauro & & \\
\hline & La Conseguí & & & \\
\hline & & & 12 & 2.4 \\
\hline & & & 216 & 44.0 \\
\hline \multicolumn{5}{|l|}{$1981-2000$} \\
\hline \multicolumn{5}{|l|}{ Names } \\
\hline Agost & Estívariz & Norber & & \\
\hline Alagarda & Eva & Orenga & & \\
\hline Allschwill & Evir & Palleter & & \\
\hline
\end{tabular}


TABLE 2

CONTINUED

\begin{tabular}{|c|c|c|c|c|}
\hline Time Period & & & Number of Names & Percent \\
\hline Almu & Gabino & Patricia & & \\
\hline Amaralina & García & Pilar & & \\
\hline Amelia & Gaspar & Pilar & & \\
\hline Angelines & Gemaida & Pololo's & & \\
\hline Araceli & Gertrudis & Quimeta & & \\
\hline Aries & Helios & Ribalta & & \\
\hline Arlequín & Hermenegildo & Rius & & \\
\hline Arlette y Vicente & Hurtado & Roig & & \\
\hline Asdi & I.P. & Rokiski & & \\
\hline Beatriz & Joana & Rosalía & & \\
\hline Bernat & Josacho & Rosa Magda & & \\
\hline Callao & Josefina & Rosemary & & \\
\hline Cardona & loyja & Rumah-Saya & & \\
\hline Carmen Adela & Kikorola & Sagrario & & \\
\hline Celia & Los Príncipes & San Jaime & & \\
\hline Chassan-Boulos & Luján & Sanjuán & & \\
\hline Chedes & Magdala & Santa Eulalia & & \\
\hline Cotolino & Magne & Santos & & \\
\hline Crisco & Maimen & Sara & & \\
\hline Dienina & Manuel & Sonia & & \\
\hline Eben-Ezer & Manuela & Susan & & \\
\hline Ediben & Maral & Sylvia & & \\
\hline El Cid & Marelén & Tauro & & \\
\hline El Palleter & Margarita & Tavi-Roc & & \\
\hline El Paraiso & María Luisa & Toki-Eder & & \\
\hline Emilia & Marilis & Trini & & \\
\hline Emperador & Mariló & Verónica & & \\
\hline Encarna & Mateu & Vicente & & \\
\hline Erijer & May-Vir & Villa de Dios & & \\
\hline Esperanza & Mayoki & & & \\
\hline \multirow[t]{2}{*}{ Esther } & Merbea & & & \\
\hline & & & 100 & 20.3 \\
\hline \multicolumn{5}{|l|}{ Places } \\
\hline Ademuz & Eivissa & Portobello & & \\
\hline Al Andalus & Els Terrers & Portofino & & \\
\hline Albayda & Eurokasim & Racó d’Or & & \\
\hline Alborán & Fadrell & Riviera & & \\
\hline Astoria & Formentor & San Marino & & \\
\hline Atlanta & Gran Avenida & Sapporo & & \\
\hline Benilandia & Gran Sol & Taal & & \\
\hline Beni-Baró & Itaca & Tanzania & & \\
\hline Beniluz & Jamaica & Tarapoto & & \\
\hline
\end{tabular}


TABLE 2

CONTINUED

\begin{tabular}{|c|c|c|c|c|}
\hline Time Period & & & Number of Names & Percent \\
\hline Benipal & lava & Taxco & & \\
\hline Boreal & La Plana & Tebas & & \\
\hline Borinquén & Laredo & Toronto & & \\
\hline Brasilia & L'Illa & Tropicana & & \\
\hline Cabo Sunión & Marbella & Vía Apia & & \\
\hline Carallot & Mónaco & Viena & & \\
\hline Centrocasim & Monte Gala & Villa Real & & \\
\hline Ciudad Ibicenca & Nueva Ibiza & Villacasim & & \\
\hline Ciudadela & Nueva Orleans & & & \\
\hline Costa Brasil & Onuba & & & \\
\hline \multirow[t]{2}{*}{ Costa de Marfil } & Palm Beach & & & \\
\hline & & & 57 & 11.6 \\
\hline \multicolumn{5}{|l|}{ Sea and Sun } \\
\hline 3 Carabelas & Els Terrers & Randumar & & \\
\hline Aigua Blava & L’Estiu & Rocamar & & \\
\hline Aireola & La Cascada & Sus mar & & \\
\hline Alba & La Falúa & Trinimar & & \\
\hline Arenal & Las Salinas & Tumar & & \\
\hline Bajamar & Mediterráneo Playa & Urbamar & & \\
\hline Barlovento & Mediterráneo Vela & Urbesol & & \\
\hline Benisol & Miraplaya & Villamar & & \\
\hline Broncemar & Olimpo & Xaloc & & \\
\hline Buenabrisa & Panasol & Yolimar & & \\
\hline Carymar & Pelillos a la Mar & & & \\
\hline Castellmar & Playamar & & & \\
\hline Cortemar & Playasol-1 & & & \\
\hline Cortesol & Playasol-2 & & & \\
\hline Cristal Mar & Poseidón & & & \\
\hline \multicolumn{5}{|l|}{ Delta } \\
\hline \multicolumn{5}{|l|}{ Dosbemar } \\
\hline & & & 42 & 8.5 \\
\hline \multicolumn{5}{|c|}{ Vegetation and Crops } \\
\hline Benazahar & L’Olivera & Los Pinos & & \\
\hline Botánico & La Grandalla & Pinarlandia & & \\
\hline El Blatet & Las Palmeras & Romerets & & \\
\hline El Tamaral & Los Almendros & & & \\
\hline \multirow[t]{2}{*}{ Els Gínjols } & Los Chopos & & & \\
\hline & & & 13 & 2.6 \\
\hline \multicolumn{5}{|l|}{ Architecture } \\
\hline Carrerassa & La Barraca & Torremar & & \\
\hline El Aljibe & La Grandalla & Vía Apia & & \\
\hline
\end{tabular}


TABLE 2

CONTINUED

\begin{tabular}{|c|c|c|c|c|}
\hline Time Period & & & Number of Names & Percent \\
\hline El Balcó & La Villeta & Villa Magna & & \\
\hline El Casetó & Las Terrazas & Villaslandia & & \\
\hline El Chalé & Mas Castell & & & \\
\hline El Cortijo & Mas Vell & & & \\
\hline \multicolumn{5}{|l|}{ El Pabellón } \\
\hline & & & 17 & 3.4 \\
\hline \multicolumn{5}{|l|}{ Other } \\
\hline Acata & Géminis & $\mathrm{Ra}$ & & \\
\hline Albórbola & Gongar & Sotileza & & \\
\hline Aldraba & Gure Am & Syca & & \\
\hline Argenta & Hellebo & Toroel & & \\
\hline Bersoca $(\mathrm{H})$ & Koala & Villa de Dios & & \\
\hline El Paraíso & Olimpo & & & \\
\hline El Perdido & Orouna & & & \\
\hline \multicolumn{5}{|l|}{ Embrujada } \\
\hline & & & 20 & 4.0 \\
\hline & & & 241 & 49.1 \\
\hline Total & & & 491 & 99.5 \\
\hline
\end{tabular}

SOURCE: Authors' Field Surveys.

forces in the war or the history the International Brigades whose convalescing soldiers were billeted in Benicàssim, but who came from France, the United States, and the countries of eastern Europe.

Changes in names were numerous. The Hotel Voramar was utilized as a hospital, renamed and dedicated to Largo Caballero, a Spanish politician and the Republican government's prime minister in I936-37. The Villa La Torreta, just behind and across the street from the hotel, was renamed for General Miaja, president of the Republic's Junta of Defense of Madrid. His name was written across the front of the porch in large black letters. About 50 meters to the south along the beach, the villa now known as "Méndez Vigo," carried the name of "Álvarez del Vayo," a politician and writer from Asturias who served as the Republic's minister of exterior during the civil war. The Villa Beutel was renamed to honor the Republican President Azaña. Other names came from the brigades of the Internationalists. The Villa Victoria, built in I9I I, was occupied and renamed as the "Villa Cultural Máximo Gorky," for the well-known Russian novelist who wrote The Enemies and The Mother. The Villa María, an immense beachfront property further to the southwest, was also renamed to "Villa Paulov" by Internationalists from Czechoslovakia in honor of this early Nobel laureate in medicine from their homeland.

\section{Post Civil War (1940-1960)}

The twenty years following the end of the Spanish Civil War were those of economic hardship for most Spaniards. Second-home ownership, either of villas or apartments, was a luxury within reach of only a very few. During these years there was little new 
construction. Only I 5 residential dwellings (about 3.I percent of the total) date from this period and carry residential names (Table 2). Villa Elisa, an imposing and palatial villa with associated gardens, now owned by the municipal government, was one of the few. It was constructed in 1943 by a political figure of the period, Conde Bau. The few other, and decidedly more modest residential building projects of the period, included villas which also carried the names of women (Iluminada, Gloria, Antoñita, and Paquita), surnames (e.g. Camilleri), and for the first time the name of a country was used in Benicassim to name a residential property. In this case, it was not a villa or apartment building, but a youth hostel opened by the provincial government, and named to honor Argentina one of the few countries to maintain diplomatic relations with Spain during the Franco dictatorship. At the end of this post-war period, the first apartment building, a five-story structure, was constructed in a newly urbanizing section of the beachfront near the seventeenth-century coastal lookout called the Torre Sant Vicent. This new apartment complex was dubbed “Torrecasim," an invented, compound word, using a Spanish and an Arabic word. This was a naming convention that would become more common in the later decades of the twentieth century.

\section{Precursors to globalization (1961-1980)}

Of the nearly 500 names recorded in this study, nearly 45 percent (215) belong to buildings constructed between 1960 and I980. It was during this period that the urban landscape of Benicàssim was radically transformed by the construction of many highrise apartment buildings, especially along the southern margins of the municipality's coastal area.

During this new building boom, personal names continued to be the most commonly selected to identify these dwellings. Nevertheless, during this period names declined in relative importance as residential toponyms, representing only about 30 percent of the post-war period's total. Women's names continued to be most common (e.g. Cristina, Margarita, Clotilde, and Carlota). Diminutives and nicknames are also used in some cases, Francis (Francisca), Jany (Juana), Lolín (Dolores) and Lledoneta (María del Lledó). Perhaps as a sign of changing times, the names of men appear in use as residential toponyms for the first time in Benicassim (Manolo, Ygor, and Don Pepe).

Surnames also figured among the toponyms used for dwellings during this period. Fifteen were identified. Generally these names were associated with single-family dwellings (e.g. villas) which were constructed early in this time period. Valencian (Casañ and Roig) and Castilian (Romero and Galván) surnames dominated, and only one surname of foreign origin, perhaps Arab, was identified (Jarrub).

Other kinds of names are used as well. Santa Águeda, a Catholic saint, is the name of a mountain that lies behind the town as well as the name for the town's only elementary school. Developers used it to name a new apartment complex built during this period. Names from literature and history appear as well. Two adjoining apartment blocks carry the names of Don Quijote and Dulcinea, characters from Cervantes novel, Don Quijote, while others are named for characters (Tombatossals and Garxolí) from the work of local literary notable, Josep Pasqual Tirado.

The sea, the sun, the sky, and the environment are used in one way or another, often in combination, to account for a many of the residential place names used 
during this period of urban development in Benicàssim. These account for about one-quarter (fifty-two names) of all those used between I960 and I980. Compound names, often invented, which describe the sea (mar) and its enchantments are abundant (e.g. Benimar, Claramar, Vistamar, Montemar, Azulmar, Cumbremar, Peñamar, Villalmar, Miramar, Blaumar, Marenostrum, Terramar, Mar-fí, Serramar, and Mar Libre). The wind (viento) and sea breezes are another common theme (e.g. Ventolera, El Gregal, Bonaire, and Tramontana). The sun, an indispensible companion for any satisfying beach holiday, is invoked in one way or another (e.g. Solimar, Helios, Heliopólis, and Cumbresol). Maritime animals and wildlife are also honored and their names used for some residential topoymns (Los Delfínes, Coral, Delfín, and La Gaviota). Finally, other maritime motifs are invoked including those related famous voyages or vessels (e.g. Kon-Tiki and Calipso) and geographical referents associated with the coast and sea (L'Illa, Las Islas, Las Rocas, and El Faro).

At the end of the I970s, tourism began to develop on a mass scale in Spain and visitors from other countries, especially France, Germany, and Great Britain became increasingly common. This phenomenon is reflected in some measure in the naming that occurred in Benicàssim as developers sought names of exotic and exciting places to enhance the attractiveness of their developments. Almost without exception, geographic places were used as the names for large condominium and apartment complexes at the time. Nearly one-quarter of all names used during this period $(n=49)$ fell into this category. Spanish place names are most common (e.g. Ordesa, Canarias, Montserrat, Columbretes, Ibiza, Montornés, Benicasim), while other notable patterns include European and American names (Venecia, Coimbra, Capri, San Remo, Las Vegas, Acapulco, and Miami) and finally places even more distant and exotic (e.g. Bali, Hawaii, Tahití, and Sydney).

Other names, totaling about 20 percent of the period's total $(n=40)$, accounted for the remainder. These include a fair number referring to plants, usually local agricultural crops (Los Naranjos, Los Olivos, Tamarindos, Les Parres) or local vegetation (Los Sauces, Los Eucaliptos, Tres Pinos). Another category of names, identified here as "Construction," invoked images of the built environment (Gran Avenida, El Poble), architectural elements (Los Arcos, La Torre), or rural agricultural constructions (La Noria, El Rancho). Finally, a range of miscellaneous topoymns, some falling into several other of the categories, and others not $(n=I 6)$, account for the balance of the names.

\section{Post-Modernity and banality (1980-2000)}

During the last two decades of the twentieth century, Benicassim's beachfront, and most of the remaining open space behind it, has been completely built-up. Highdensity dwellings, mostly eight- to ten-story apartment buildings, are common and account for about half of the urban development. Villas, condominiums, and other lower density residences occupy the rest of the urban space. Just about half of all the buildings cataloged in this study, 237, were built during this twenty-year period. In terms of urban development, this period is characterized by the construction of a large number of single-family semi-detached structures as alternatives to apartments. In part this represents something of a return to the origins of the tourist landscape of Las Villas during the early part of the twentieth century when single-family dwellings were the rule. 
The naming patterns during the last two decades of the twentieth century reflect both similarities with past customs and some modern twists. Names, personal and surnames, represent almost 45 percent of the toponyms used for residential dwellings. Women's names are again most significant, over one-half (Table 2). Many of these are traditional women's names, but some are unique, or perhaps just post-modern, like Kikorola, Pololo, or May-Vir. Notwithstanding, surnames continue to figure in the naming patterns and reflect Spanish, Valencian (Catalan), and other influences (e.g. García, Rius, Ruman Saya, and Allschwill).

Geographic names continue to be commonly used and represent close to 20 percent of the period's total. Names of far off lands and exotic locales continue to be frequently employed as toponyms, usually on apartment buildings and condominium complexes. But local names still occur as do Spanish place names. Among Spanish places, the island of Ibiza figures prominently, especially for names of semi-detached residential complexes. Variants include Ciudad Ibicenca, Nueva Ibiza, and Eivissa. There has also been a trend to create names that somehow reflect the image of the town. There is a certain banality about some of these names, created by adding a made-up Spanish suffix, "landia," to various names, thus, Benilandia and Villaslandia. Alternatively the name "kasim," "casim," or "cassim," is used as a suffix to create other names (e.g. Eurokasim and Villacasim). The name itself comes from Arabic and is derived from the town's name, Benicàssim, meaning in Arabic, "sons of Cassim".

Again, the sea and the sun are integral components in the naming patterns in this last period of analysis, with about 20 percent of the total incorporating words associated with these images. More often than not, these sorts of names are associated with large apartment complexes and serve in some fashion as advertisements. These names include Vistamar, Playamar, Playasol, Miraplaya, and Mediterráneo Playa.

The remaining 20 percent of the observations recorded for this period fell into three broad groups all of about equal number. These groups include one with names relating to architectural or construction themes (La Villeta, El Chalé, El Aljibe, and El Cortijo), another focusing on plants and gardens (Las Palmeras, Els Ginjols, L'Olivera, and Los Pinos), and a more varied miscellaneous groups (Villa de Dios, Hellebo, Mayoki, El Perdido, and Embrujada).

\section{Conclusion}

The use of names to identify residential dwellings has a long history in Benicàssim, beginning at the end of the nineteenth century and continuing until the present day. The use of personal names and surnames has been most common and these account for nearly 40 percent of all residential toponyms. While the use of personal and surnames was most common late nineteenth century and early twentieth, they are still the most commonly used toponyms to identify single-family dwellings at the beginning of the twenty-first century.

These two categories of names are used almost exclusively on single-family dwellings, and women's names are overwhelmingly dominant. Men's names are used in only a few cases and these instances on apartment buildings. In only one case was a woman's name associated with an apartment building in Benicàssim. This represents a fascinating contrast to the patterns of apartment building naming found in a study of apartment building names in New York City (Norton and Patterson, 1984) where 
women's names were used with considerable frequency in the naming of apartments at the end of the nineteenth century, as were names of saints and English counties. A study of more recent apartment naming patterns in the United States suggests that names invoking pleasant environments, "greener" names have become more common (Koegler, I986).

Two categories of names, geographical referents and those invoking images of the sun and the sea, each account for about 20 percent of all residential toponyms. These terms, however, are rarely used to identify single-family residences and are used almost exclusively to name apartment buildings, condominium complexes, and other multi-unit residential dwellings. These toponyms often include the names of exotic or far-away tourist destinations in Spain, Europe, or further afield in the Americas. The use of these names did not become widespread until after the I960s when mass tourism became common in Benicàssim and in Spain generally.

A potpourri of other names, including those relating to mythology, nature, and architecture and construction, represent the balance of those used in Benicassim. These typically have been most commonly used in the last decades of the twentieth century and are associated with apartment buildings and condominium complexes.

A notable recent trend has been the use of made-up names, usually referring to the local scene or environment. These are often created by combining suffixes like "landia" (a made-up Spanish word for the English word land) and "Cassim" (the Arabic word for tribal group) with another referent. The use of "Beni" is also become common as a prefix for other made-up toponyms used in the town.

While it is difficult to assign motivations for specific naming patterns and conventions used in Benicassim during the period of the study with any certainty, one can speculate. Names used for single-family dwellings, villas and the like, are typically "personal" in some way and suggest motivation. Women's names, especially on single-family dwellings, have figured prominently among the names used throughout the entire period. Local lore and practice suggests that in almost all cases these dwellings were given female names by loving husbands to honor their wives. Similarly, the use of surnames, though not as common as women's names, is almost always used as a means of recognizing a family's history and dominion over a particular singlefamily residence. Other names used for single-family dwellings represent an eclectic mix and defy easy understanding. Naming conventions for apartment buildings or condominium complexes may be easier to explain. In many cases the names of exotic places, vacation sites, or famous locations are used. One assumes that the idea is to create the image of the apartments or condominiums as being linked to an exciting locale. In other cases, apartments and condominiums are named using conventions that link the image of the place to a pleasant environment, reflecting perhaps elements of the beach, the sun, the surf, or the mountains that characterize Benicàssim's environment. Finally, developers and builders will use other names to invoke a sense of grandeur for multi-unit developments, for instance, calling them the Ambassador or the Princes.

\section{Acknowledgements}

Financial support for the field research and preparation of this paper is gratefully acknowledged. Thanks are due to the Universitat Jaume I through its Programa de Movilidad de Personal Investigador. Estancia de Investigadores No. I Io06. I5/I. 


\section{References}

Aguilar Civera, Inmaculada ed. 2006. Benicàssim y la historia del ferrocarril. Valencia: Conselleria d'Infraestructures

i Transport.

Bright, William. 2004. Colorado Place Names. 3rd ed. Boulder, CO: Johnson Books.

Burriel Orueta, Eugenio. 2008. Personal communication. June I4.

Cameron, Kenneth. 1985. The Place-Names of Lincolnshire. Nottingham: English Place Name Society.

Ekwall, Eilert. 1960. The Concise Oxford Dictionary of English Place-Names. $4^{\text {th }}$ ed. Oxford: Clarendon Press.

Empson, Donald and Kathleen M. Vadnais. 2006. The Street Where You Live: A Guide to the Place Names of St Paul. Minneapolis, MN: University of Minnesota Press.

Ginés Escuder, A. 1972. Geografía agraria de Benicàssim. Valencia: Universidad de Valencia. Suplemento de Saitabi. $35 \mathrm{pp}$.

Gudde, Erwin G. 1998. California Place Names: The Origin and Etymology of Current Geographical Names. 4th ed. revised and enlarged by William Bright. Berkeley: University of California Press.

Hipólito Sesé, Maria Dolors. 2002. "Els noms dels centres d'Ensenyament a Barcelona." Societat d'Onomàstica (Barcelona) I04-I05: 9-36.

Hoffmann, P. I992. “Tourism and language in Mexico's Los Cabos." Journal of Cultural Geography I2(2): 77-92.

Johnston, James Brown. 1903. Place-names of Scotland. 2nd ed. Edinburgh: D. Douglas.

Koegler, Karen. 1986. "A Farewell to Arms: The 'Greening' of American Apartment Names.” Names 34: 48-6I. López Gómez, A. 1972. "Los masets de Castellón.” Cuadernos de Geografía (Valencia) II: I-6.

Mathews, Constance Mary. 1972. Place Names of the English-speaking World. New York: Scribner.

McNamara, J. I99I. History in Asphalt: The Origin of Bronx Street and Place Names. 3 rd ed. New York: Bronx County Historical Society.

Mills, A. D. 2004. A Dictionary of English Place-names. London: Oxford University Press.

Millward, Celia and Richard Millward. 1984. "Ski-trail Names: A New Toponymic Category." Names 32 : I9I-2I7.

Nácher Escriche, J. I996. Turismo litoral y desarrollo económico local: Una aproximación territorial al caso de Benicàssim. Doctoral Thesis. Facultad de Ciencias Económicas, Universidad de Valencia.

Norton, Thomas E. and Jerry E. Patterson. 1984. Living it Up: A Guide to the Named Apartment Buildings of New York. New York: Atheneum.

Ortells Chabrera, Vicent. 2005. "La industria cerámica a la Plana de Castelló. Tradició histórica i mundialització actual." Treballs de la Societat Catalana de Geografia 58: 35-66.

2006. "El ferrocarril y la construcción urbana: De una villa del Camino Real a la ciudad-red del siglo XXI." Benicàssim y la historia del ferrocarril, ed. Inmaculada Aguilar Civera. Valencia: Conselleria d'Infraestructures i Transport, $57-82$.

Pacione, M. I977. "Tourism: Its Effects on a Traditional Landscape in Ibiza and Fomentera." Geography 62: $43-47$.

Parsons, James J. 1973. "Southward to the Sun: The Impact of Mass Tourism on the Coast of Spain." Yearbook of the Association of Pacific Coast Geographers 35: I29-I45.

Piñón, J.L. and L.A. Armiño. I982. "Una historia sencilla de una transformación urbana. Las Villas de Benicàssim." Cimal (Valencia) I8: 28-32.

Quereda Sala, José. I979. Benicasim y la espectular transformación de su paisaje. Castellón: Diputación Provincial de Castelló. II 5 pp.

Room, Adrian. I992. "Saints and Sites: The Interrelationship Between Church Dedication and Placenames in England." Names 40: 26I-270.

Sarthou Carreres, C. I9I0. Impresiones de mi tierra. Valencia: Biblioteca Grafica Valenciana-I. Reprint of the original edition, I984.

Stewart, George R. 1970. American Place-Names; a Concise and Selective Dictionary for the Continental United States of America. New York: Oxford University Press.

Stump, Roger. 1988. "Church-naming Practices among Eastern Rite Catholics in the United States." Names 36: $85-90$. 
Tarpley, Fred. 2006. "Naming America's Graveyards, Cemeteries, Memorial Parks, and Gardens of Memories." Names 54.2: 9I-IOI.

Verge Caballer, Joan Antoni. 2006. "Significació dels toponims rurals del terme de Rossell." Actes de la I Jornada d'Onomástica Sant Mateu 2006. Valencia: Academia Valenciana de la Llengua, 2I7-233.

Vogel, Virgil J. 1983. Iowa Place Names of Indian Origin. Iowa City: University of Iowa Press.

Wichman, Frederick B. I998. Kana'i: Ancient Place-names and Their Stories. Honolulu: University of Hawaii Press.

Wilhelm, Albert E. I988. "Pretty is as Pretty Says: The Rhetoric of Beauty Salon Names.” Names 36: 6I-68.

Zelinsky, Wilbur. I990. "A Toponymic Approach to the Geography of American Cemeteries." Names 38: 209-229. . 2002. "Names of Chicago's Churches: A Tale of (at least) Two Cultures." Names 83-I03.

\section{Notes on Contributors}

Vicent Ortells Chabrera (University of Valencia, Spain, Ph.D.) is Professor of Urban Geography at Universitat Jaume I, Castelló de la Plana, Spain. His research and publication focus on urban planning, human geography, toponymy, and patrimony, in both Spain and Latin America. He lives in Villarreal (Spain) with his wife, Lidón, and sons, Pablo and Raul.

Robert B. Kent (Syracuse University, Ph.D.) is the department chair and the James H. Ring Professor of Urban Studies and Planning at California State University, Northridge. His research and publication focus on urban and regional planning, human geography, Latin America, and cartography/GIS. In I998-99 he was a visiting scholar at the Universitat Jaume I in Castelló de la Plana, Spain. He lives in the Porter Ranch neighborhood of Los Angeles, CA with his wife, Marialena.

Correspondence to: Robert B. Kent, Department of Urban Studies and Planning, California State University Northridge, I8I I I Nordhoff St., Northridge, CA 9I3308259, USA. Email: rkent@csun.edu 